\title{
Jumlah Bakteri pada Luka Diabetik Kronik yang Dicuci Menggunakan Ekstrak Air Daun Jambu Biji (Psidium Guava)
}

\author{
Fahni Haris \\ Universitas Muhammadiyah Yogyakarta \\ Jl. Lingkar Selatan, Kasihan, Tamantirto, Bantul, Daerah Istimewa Yogyakarta 55183, Indonesia \\ Email: fahni.h@umy.ac.id
}

\begin{abstract}
Abstrak
Berbagai cairan pencuci luka telah digunakan diantaranya normal saline. Ekstrak air daun jambu biji diketahui memiliki kandungan yang dapat dimanfaatkan sebagai bahan antibakteri pada perawatan luka diabetes militus terutama saat cleansing. Selain normal saline, ekstak air daun jambu biji banyak digunakan karena tersedia di Indonesia akan tetapi fungsi dari ekstrak air daun jambu biji masih banyak diperdebatkan. Tujuan penelitian untuk mengkaji kegunaan ekstrak air daun jambu biji dalam menurunkan jumlah koloni bakteri pada luka diabetik kronik. Metode penelitian eksperimen semu dengan pendekatan pre test post test design. Sampel penelitian terdiri dari 20 pasien dengan luka diabetik kronik yang berkunjung di klinik Kitamura, Pontianak selama satu bulan. Menggunakan analisis kuantitatif non parametrik, dengan uji wilcoxon dan uji mann whitney untuk mengetahui pengaruh ekstrak air dalam menurunkan koloni bakteri. Hasil penelitian terdapat penurunan jumlah koloni bakteri setelah dilakukan pencucian luka dengan menggunakan ekstrak air daun jambu biji 20\%. Nilai p-value pada hari ke-1 sampai hari ke-7 untuk kelompok Jambu 10\% adalah $p=0,008$ $(p<0,05)$ dan kelompok Jambu $20 \%$ adalah $p=0,003$ ( $p<0,05)$. Kesimpulan tidak ada perbedaan jumlah koloni bakteri antar kelompok dengan nilai $p=0,368(p>0,05)$, akan tetapi pencucian luka dengan bahan ekstrak air daun jambu biji $20 \%$ lebih efektif menurunkan jumlah koloni bakteri dengan nilai $p=0,003 \quad(p<0,05)$.
\end{abstract}

Kata Kunci: luka diabetik, pencucian luka, ekstrak air, daun jambu biji

\section{Bacteries Load on Chronic Diabetic Foot Ulcer Using Aqueous Guava Leaf Extract (Psidium Guava) as Wound Cleanser}

\begin{abstract}
Various solutions have been recommended for cleanse the wound, however normal saline is favored. Aqueous guava leaf extracts have material that known for antibacterial in the diabetic wound care especially for cleansing. Guava leaf available in Indonesia, but there is unresolved debate about its use. This study use quasi-experimental with pre-test post-test design. Sample in this study consist 19 outpatients who had diabetic chronic wounds care in clinic Kitamura, Pontianak. Analysis of quantitative data was tested with non-parametric analysis, Wilcoxon test and Mann Whitney test to determine the effect of aqueous guava leaves extract in reducing bacterial. Results sowed that he number of bacteria colonies after cleansing the wound using aqueous guava leaves extract was decreased. P-value on first day until seventh day for $10 \%$ aqueous guava leaves was $p=0.008(p<0.05)$ and $20 \%$ aqueous guava leaves extract was $p=0.003(p<0.05)$. In conclusion, there was no differences number of bacterial colonies between group $p=0.368(p>0.05)$, but $20 \%$ aqueous guava leaves extract most effective than $10 \%$ aqueous guava leaves extract.
\end{abstract}

Keywords: diabetic ulcer, wound cleansing, aqueous extract, guava leaf

Info Artikel:

Artikel dikirim pada 10 Mei 2017

Artikel direvisi pada 28 Agustus 2017

Artikel diterima pada 18 September 2017

DOI: http://dx.doi.org/10.21927/jnki.2017.5(2).106-114 


\section{PENDAHULUAN}

Masalah kaki diabetik (ulserasi, infeksi, dan gangren) adalah penyebab utama indikasi pasien diabetes untuk rawat inap1. Perawatan luka yang berkelanjutan, pencegahan infeksi, amputasi, dan rawat inap pasien menghabiskan miliaran dolar setiap tahun dan menjadi beban besar bagi sistem pelayanan kesehatan (1). Penduduk di negara miskin dan berkembang meninggal setiap tahunnya karena diabetes $(80 \%)$, termasuk didalamnya karena luka diabetic (2).

Kurangnya pemahaman tentang waktu dan proses penyembuhan luka adalah keluhan utama yang menjadi penyebab meningkatnya frustasi, depresi, dan keterbatasan aktivitas sehari-hari pada pasien dengan luka diabetic (3). Proses penyembuhan luka diabetik berkaitan erat dengan manajemen atau teknik perawatan luka yang terdiri dari cleansing, debridement dan dressing (4). Komponen-komponen perawatan luka di atas saling mendukung dalam proses penyembuhan luka, akan tetapi pencucian luka (cleansing) menjadi tolak ukur keberhasilan perawatan luka dan merupakan standar praktek perawatan luka yang selalu dilakukan oleh praktisi kesehatan profesional baik di Indonesia maupun di luar negeri (4).

Pencucian luka untuk mengurangi jumlah mikroorganisme selain menggunakan $\mathrm{NaCl} 0,9 \%$ dapat dilakukan dengan menggunakan ekstrak daun jambu biji (5). Ekstrak air daun jambu biji mempunyai kemampuan merusak protein (proteolytic) terhadap polipeptida bakteri jenis MRSA (6). Hasil skrining fitokimia ekstrak air daun jambu biji menghasilkan flavanoid, saponin, tannin, karbohidrat, steroid, protein dan asam amino yang merupakan hasil terlengkap jika dibandingkan dengan ekstrak yang lain (7). Penelitian tentang manfaat daun jambu biji sebagai bahan antibakteri sudah banyak dilakukan baik dari tahap in vitro, eksperimen hewan, uji toksisitas sampai eksperimen ke manusia (8). Di Indonesia, penelitian menggunakan ekstrak air daun jambu biji untuk pencucian luka kronik dinilai belum menjadi evidence-based (5).

Usia luka kronik DM sendiri dilaporkan bervariasi dari beberapa bulan hingga berusia lebih dari 5 tahun (1). Penyembuhan luka DM yang memerlukan waktu dan hasil sistematik review terkait ekstrak air daun jambu biji masih merupakan isu terkini yang harus diteliti. Berawal dari masalah ini tujuan penelitian ini untuk mengkaji kegunaan ekstrak air daun jambu biji dalam menurunkan jumlah koloni bakteri pada luka diabetik kronik. Mengkaji jumlah koloni bakteri sebelum dan setelah dilakukan cleansing pada kelompok ekstrak air daun jambu biji.

\section{BAHAN DAN METODE}

Penelitian ini menggunakan quasy experimental dengan pendekatan pre-test post-test control group design untuk melihat pengaruh cleansing menggunakan ekstrak air daun jambu biji dengan komposisi $10 \mathrm{~g} / 100 \mathrm{ml}$ dan $20 \mathrm{~g} / 100 \mathrm{ml}$ (9). Penelitian ini dilakukan pada bulan Desember 2013 di Klinik Kitamura, Pontianak. Ekstrak air daun jambu biji dibuat sendiri oleh peneliti sesuai dengan prosedur. Populasi terjangkau yang diambil yaitu pasien dengan luka kronik yang berkunjung dan mendapatkan perawatan luka di Klinik Kitamura Pontianak. Jumlah pasien perbulan November-Desember 2013 sebanyak 123 pasien.

Menggunakan Consecutive Sampling dengan cara semua subyek yang datang ke klinik Kitamura dan memenuhi kriteria pemilihan dimasukkan dalam penelitian sampai jumlah subyek yang diperlukan terpenuhi yaitu dalam jangka waktu satu bulan (11). Peneliti mendapatkan 22 responden dengan 2 diantaranya dropout sehingga responden yang mengikuti penelitian sampai selesai sebanyak 20 orang dengan kriteria inklusi pasien rawat jalan yang mempunyai luka kronik dengan umur luka lebih dari tiga minggu dirawat oleh perawat klinik Kitamura, Pontianak dengan rentang umur 30 - 80 tahun dan bersedia menjadi responden.

Bahan-bahan yang digunakan yaitu ekstrak air daun jambu biji (Psidium guajava Linn.), kassa steril, hypafix, akuades, sabun antiseptik, kertas saring, tisu, serbet, dressing luka. Alat yang digunakan yaitu set medikasi steril, swab set, spuit 50cc, jarum spuit 20G, sarung tangan steril, sarung tangan disposibel, cool box, mikroskop.

Daun jambu biji dibeli dari PT Bina Syifa Mandiri, Yogyakarta. Proses daun jambu biji menjadi simplisia yaitu daun dikeringkan dalam suhu rumah selama sehari (24 jam) kemudian dirajang halus dengan ukuran 0,5-4 mm. Bahan uji disediakan $20 \mathrm{gr}$ kemudian masing-masing bahan direndam selama 12 jam (dari jam $20.00-08.00$ ) dalam $100 \mathrm{ml}$ aquades untuk mendapatkan ekstrak air daun jambu biji. Ekstrak siap dijadikan bahan untuk digunakan cleansing pada luka kronik (10). 
Perawatan luka difokuskan pada cleansing, tetapi semua langkah tetap dilakukan. Langkahlangkah untuk perawatan luka dapat dijelaskan sebagai berikut: Pembersihan luka (cleansing) yaitu membersihkan luka dengan menggunakan cairan antiseptik (sabun luka) kemudian disemprotkan dengan ekstrak air daun jambu biji 10\% dan $20 \%$ menggunakan spuit 50cc dan jarum 20G. Pencucian luka dilakukan tiga siklus untuk setiap pasien. Pengangkatan luka (debridement) yaitu melakukan pengangkatan jaringan yang sudah mati dengan menggunakan set medikasi steril (gunting jaringan, pinset anatomis, pinset sirurgis). Penutupan (dressing) yaitu melakukan pembungkusan luka dengan menggunakan balutan yang disesuaikan dengan order masing-masing dokter yang menangani pasien.

Swabbing menggunakan kapas lidi steril dengan penguapan kering diatas suhu $100^{\circ} \mathrm{C}$ selama 30 menit di klinik Kitamura yang dibasahi $\mathrm{NaCl}$ dan diusapkan ke bagian luka, usapan dilakukan secara zig-zag sampai mengenai semua area luka. Kapas lidi segera dimasukkan ke dalam $\mathrm{NaCl} 0,9 \%$ sebanyak 4cc pada tabung reaksi tertutup agar tidak kering, diberi label dan segera dikirimkan ke laboratorium dengan menggunakan cool box untuk proses penghitungan. Cool box bisa digunakan jika sampel hasil swabbing tidak bisa dikirimkan segera, maksimal 24 jam. Setiap kelompok (Jambu 10g/100ml dan 20 $\mathrm{g} / 100 \mathrm{ml}$ ) dilakukan satu siklus swabbing baik sebelum maupun sesudah cleansing.

Data yang didapat dalam penelitian ini selanjutnya dianalisis dengan uji normalitas data menggunakan uji Kolmogorof Smirnov atau Shapiro Wilk $(p>0,05)$. Hasil uji normalitas didapatkan data tidak terdistribusi normal, sehingga peneliti menggunakan uji non parametrik. Uji Wilcoxon digunakan sebagai uji t-berpasangan untuk mengetahui signifikansi ( $p$-value) pengaruh mencucian luka. Uji One way anova (Kruskal Wallis) dilakukan untuk mengetahui perbedaan yang signifikan disemua kelompok uji coba (precleansing dan post cleansing). Uji Mann Whitney dilakukan untuk mengetahui signifikansi diantara kelompok-kelompok uji coba (post cleansing) diantara kelompok.

\section{HASIL DAN BAHASAN}

Karakteristik demografi responden dalam penelitian ini mencakup jenis kelamin, usia, ratarata gula darah sewaktu, rata-rata lama responden mengalami luka dan rata-rata jumlah koloni bakteri responden.

Tabel 1. Distribusi Responden Berdasarkan Jenis Kelamin di Klinik Kitamura Pontianak, Desember $2013(n=20)$

\begin{tabular}{|c|c|c|c|c|c|c|}
\hline \multirow[t]{2}{*}{$\begin{array}{l}\text { Jenis } \\
\text { Kelamin }\end{array}$} & \multicolumn{2}{|c|}{$\begin{array}{c}\text { Ekstrak } \\
\text { Daun } \\
\text { Jambu Biji } \\
10 \%(n=10)\end{array}$} & \multicolumn{2}{|c|}{$\begin{array}{c}\text { Ekstrak } \\
\text { Daun } \\
\text { Jambu Biji } \\
20 \%(n=10)\end{array}$} & \multicolumn{2}{|c|}{$\begin{array}{c}\text { Total } \\
\text { Responden }\end{array}$} \\
\hline & $f$ & $\%$ & $f$ & $\%$ & $\mathrm{n}$ & $\%$ \\
\hline Laki-Laki & 3 & 33,3 & 4 & 36,4 & 7 & 35 \\
\hline Perempuan & 6 & 66,7 & 7 & 63.6 & 13 & 65 \\
\hline
\end{tabular}

Responden dengan usia termuda terdapat di kelompok Jambu $20 \%$ yaitu 33 tahun dan responden tertua terdapat di kelompok Jambu $10 \%$ dengan umur responden 65 tahun.

Hasil penelitian pada Tabel 1, didapatkan penderita perempuan $(n=13)$ lebih banyak jika dibandingkan dengan laki-laki $(n=7)$. Hal ini berbeda dengan penjelasan dari studi yang menyatakan bahwa laki-laki beresiko 2,6 sampai 5,2 kali beresiko menderita luka diabetes dikarenakan hiperglikemia (3). Penyebab buruknya kontrol gula darah pada laki-laki, dikarenakan mereka merasa bisa mengatasi penyakitnya daripada perempuan, dan laki-laki beranggapan jika sakit maka akan kehilangan kehormatan sebagai seorang laki-laki (3). Berbeda dengan laki-laki, perempuan lebih bisa merawat dan segera mencari pertolongan ke pelayanan kesehatan jika merasa ada masalah pada keadaan tubuhnya (12).

Faktor gaya hidup dan hormonal juga menyebabkan laki-laki lebih beresiko terkena luka diabetes dibandingkan dengan perempuan (13). Hal ini sesuai dengan hasil wawancara dari beberapa responden laki-laki, bahwa mereka tidak rutin mengontrol kadar gula darah sebelum terjadi komplikasi luka diabetik. Anggapan beberapa responden laki-laki bahwa mereka sehat, tidak sakit karena bisa melakukan aktivitas seperti biasa dan tidak mengontrol pola makan sehari-hari.

Berbeda dengan penjelasan sebuah studi (3), penelitian ini didukung oleh American Diabetes Association yang menyatakan bahwa resiko komplikasi luka diabetik akan meningkat pada perempuan usia menopause (14). Dikarenakan perempuan menopause mengalami degenerasi hormon estrogen yang akan meningkatkan resiko kejadian neuropatik dan luka diabetik sama seperti pada laki-laki 
dengan diabetes (14). Fungsi estrogen sendiri yaitu memfasilitasi respon inflamasi pembentukan sel vaskular, memberikan nutrisi terhadap pembuluh darah, mengatur kadar lipid dan kolesterol di dalam tubuh, mengatur sensitifitas insulin dan mengatur kematian sel stem sehingga sangat menentukan untuk kelangsungan sel tubuh (15).

Rata-rata usia responden pada kelompok Jambu $10 \%$ dan kelompok $20 \%$ dalam penelitian ini tidak ada perbedaan secara statistik $(p>0,05)$ artinya kedua kelompok homogen.

Hasil penelitian pada Tabel 2 menunjukkan bahwa rata-rata responden berusia 53 tahun dan secara statistik tidak terdapat perbedaan rata-rata usia responden semua kelompok $(p>0,05)$. Semakin tua usia seseorang dengan diabetes, maka semakin tinggi resiko terkena luka. Hal ini sejalan dengan penjelasan dari studi (16) bahwa proses inflamasi, migrasi sel, proliferasi dan pematangan sel menjadi lambat, fungsi reproduksi epidermal dan sel fibroblast juga menjadi lambat pada usia Ianjut. Dalam penelitian ini, proses inflamasi yang berkepanjangan pada beberapa responden perempuan menyebabkan melambatnya proses proliferasi dan pematangan sel yang disebabkan selain faktor usia responden juga keadaan hiperglikemia responden.

Prevalensi kejadian dehiscence atau luka gagal menyambung dua sampai tiga kali lebih besar pada usia lanjut, walaupun nutrisi yang tidak adekuat, infeksi dan komplikasi pengobatan sering terjadi pada orang dengan luka diabetes. Usia juga berpengaruh pada respon sel terhadap stimulasi injuri, deposisi kolagen dan kekuatan tensil pada jaringan yang sudah sembuh menjadi lebih lambat (13). Selain faktor usia, diet yang kurang efektif pada responden menyebabkan penyaluran nutrisi tidak adekuat, serta adanya load bakteri menambah waktu penyembuhan luka responden.

Struktur ketebalan kulit responden menjadi lebih tipis, serat-serat elastin diproduksi dalam jumlah yang sedikit atau bahkan tidak lagi diproduksi sehingga kulit tidak lagi elastis. Hal ini diperparah dengan keadaan gula darah yang tinggi pada responden yang menghambat pembentukan sel-sel endothelial pada fase proliferasi dan menyebabkan tidak adekuatnya mediator-mediator angiogenesis yang berakibat asupan nutrisi, oksigen, growth factor, fibroblast tidak terpenuhi sehingga memperpanjang fase proliferasi pada saat terjadi trauma (13).

Dengan bertambahnya usia, resiko meningkatnya kejadian neuropatik semakin lama akan semakin bertambah luas jika gula darah tidak terkontrol, disamping faktor degeneratif itu sendiri. Awal kejadian neuropatik biasanya didahului dengan berkurangnya sensitivitas sensasi di ekstremitas bawah, seiring bertambahnya usia maka kejadian neuropatik akan meningkat ke tubuh bagian distal sampai menuju ke sistem gastrointestinal (13).

Pada usia lanjut, terganggunya sistem gastrointestinal mempengaruhi proses metabolik dikarenakan tidak terpenuhinya pemenuhan nutrisi oleh reseptor-reseptor di lambung yang mengalami penurunan sensasi ataupun kemampuan dalam menyerap nutrien-nutrien esensial yang dibutuhkan oleh tubuh (3). Rata-rata responden mengalami hiperglikemia dan neuropatik diarea kaki akan tetapi peneliti tidak mengkaji apakah gejala neuropatik pada responden sudah mencapai area distal atau tidak hanya saja tingginya gula darah didalam sirkulasi tubuh responden dan terganggunya penyerapan nutrisi karena hiperglikemia mengakibatkan penyembuhan luka, revaskularisasi maupun regenerasi sel responden menjadi terganggu.

Rata-rata lama luka responden pada kelompok Jambu $10 \%$ dan kelompok $20 \%$ dalam penelitian ini terdapat perbedaan secara statistik $(p<0,05)$ artinya kedua kelompok tidak homogen.

Nilai mean lama luka pada Tabel 3 didapatkan pada kelompok jambu $10 \%$ tujuh minggu dan jambu $20 \%$ dengan lama luka 23 minggu. Nilai mean lama luka kedua bahan yaitu 15 minggu, faktor utama peneliti mendapatkan lama luka yang berbeda karena dalam kriteria inklusi penelitian ini menerapkan rentang lama luka yang terlalu panjang. Perbedaan lama luka pada responden mengakibatkan semua responden mengalami kegagalan penyembuhan luka

Tabel 2. Rata-Rata Usia Responden di Klinik Kitamura Pontianak, Desember 2013 (n=20)

\begin{tabular}{cccccc}
\hline Karakteristik & Kelompok & Rata-Rata Tahun & SD & Min - Max & p-value \\
\hline Usia & Jambu 10\% & 55 & 6,89 & $43-65$ & $0,572^{*}$ \\
& Jambu 20\% & 48 & 10,08 & $33-64$ & \\
\hline
\end{tabular}

${ }^{*} p>0,05$ (data terdistribusi normal) 
Tabel 3. Rata-Rata Lama Luka Responden (minggu) di Klinik Kitamura Pontianak, Desember $2013(n=20)$

\begin{tabular}{cccccc}
\hline Karakteristik & Kelompok & Rerata Minggu & SD & Min - Max & p-value \\
\hline Lama Luka & Jambu 10\% & 7 & 4,24 & $4-16$ & $0,000^{*}$ \\
& Jambu 20\% & 23 & 30,25 & $6-112$ & \\
\hline
\end{tabular}

${ }^{*} \mathrm{p}>0,05$ (data terdistribusi tidak normal)

yang dikarenakan oleh beberapa faktor diantaranya yaitu tidak adanya homeostatis, memanjangnya fase inflamasi dan proliferasi (17). Usia luka lebih dari empat minggu seharusnya sudah dalam fase remodeling, akan tetapi dengan adanya gangguan metabolik, usia responden, penyakit sistemik penyebab inflamasi (diabetes mellitus) menyebabkan lama luka bertambah panjang dan tidak mengalami penyembuhan (16).

Tabel 4. Rata-Rata Gula Darah Sewaktu Responden di Klinik Kitamura Pontianak, Desember 2013 (n=20)

\begin{tabular}{cccc}
\hline Karakteristik & \multicolumn{2}{c}{ Kelompok } & p-value \\
\cline { 2 - 3 } & Jambu 10\% & Jambu 20\% & \\
\hline GDS (g/dL) & 233 & 212 & $0,069^{*}$ \\
\hline
\end{tabular}

${ }^{*} p>0,05$ (data terdistribusi normal)

Menurut Tabel 4 didapatkan rata-rata nilai gula darah responden tertinggi pada kelompok Jambu $10 \% 233 \mathrm{~g} / \mathrm{dL}$.

Tabel 5. Rata-Rata Jumlah Koloni Bakteri Responden di Klinik Kitamura Pontianak, Desember (2013)

\begin{tabular}{ccc}
\hline Kelompok & $\begin{array}{c}\text { Rata-Rata Jumlah } \\
\text { Koloni Bakteri (cfu/ml) }\end{array}$ & p-value \\
\hline Jambu $10 \%$ & $2,9 \times 10^{7}$ & 0,510 \\
Jambu $20 \%$ & $2,5 \times 10^{7}$ & 0,569 \\
\hline
\end{tabular}

Berdasarkan Tabel 5 didapatkan nilai $(p>0,05)$ untuk masing-masing kelompok. Artinya secara statistik, dari hasil uji normalitas data rata-rata jumlah koloni bakteri responden pada kelompok jambu $10 \%$ dan jambu $20 \%$ terdistribusi normal.

\section{Perbedaan Jumlah Koloni Bakteri}

Hasil penghitungan jumlah koloni bakteri pada pasien dengan luka kronik di klinik Kitamura, Pontianak disajikan dalam bentuk tabel di bawah ini.

Berdasarkan Tabel 6 didapatkan perbedaan yang signifikan terhadap penurunan jumlah koloni bakteri sebelum dan setelah pencucian luka pada kedua kelompok ( $p$-value: 0,008 dan 0,003 ). Hasil
Tabel 6. Perbedaan Jumlah Koloni Bakteri Sebelum dan Setelah Dilakukan Pencucian Luka pada Kelompok Jambu 10\% dan Jambu 20\% di Klinik Kitamura Pontianak, Desember (2013)

\begin{tabular}{cccc}
\hline \multirow{2}{*}{ Kelompok } & \multicolumn{2}{c}{ Jumlah Koloni Bakteri (cfu/ml) } & \multirow{2}{*}{ p-value } \\
\cline { 2 - 4 } & Pre_hari ke-1 & Post_hari ke-7 & \\
\hline Jambu 10\% & $2,9 \times 10^{7}$ & $1,4 \times 10^{4}$ & 0,008 \\
Jambu 20\% & $2,5 \times 10^{7}$ & $1,5 \times 10^{3}$ & 0,003 \\
\hline
\end{tabular}

uji statistik memaparkan bahwa jambu 10\% dan jambu $20 \%$ sama-sama efektif (signifikan, $p<0,05$ ) mengurangi jumlah koloni bakteri pada luka. Dengan formula selisih jumlah koloni bakteri (pre_hari ke-1) dan (post_hari ke-7) dikalikan 100\% pada Tabel 6, maka kelompok jambu $10 \%$ dan jambu $20 \%$ efektif rata-rata menghilangkan 99,95\% dan 99,99\% koloni bakteri.

Perbedaan Jumlah Koloni Bakteri Setelah Dilakukan Pencucian Luka

Hasil penghitungan perbedaan rata-rata jumlah koloni bakteri pada pasien dengan luka kronik di klinik Kitamura, Pontianak disajikan dalam bentuk tabel di bawah ini.

Tabel 7. Perbedaan Rata-Rata Jumlah Koloni Bakteri pada Responden di Klinik Kitamura Pontianak, Desember 2013 ( $N=20)$

\begin{tabular}{lcc}
\hline Kelompok & $\Delta$ mean (cfu/ml) & p-value \\
\hline Jambu $10 \%$ & $2,8 \times 10^{7}$ & $0,368^{*}$ \\
Jambu $20 \%$ & $2,5 \times 10^{7}$ & \\
\hline
\end{tabular}

${ }^{*} p>0,05$

Berdasarkan Tabel 7 menggambarkan perbedaan jumlah koloni bakteri setelah dilakukan pencucian luka. Dari uji statistik Kruskal-Wallis didapatkan nilai $p=0,368(p>0,05)$, artinya pada setiap kelompok (Jambu 10\% dan Jambu 20\%) tidak terdapat perbedaan rata-rata jumlah koloni bakteri setelah dilakukan pencucian luka dari hari ke-1 (pre_1) sampai hari ke-7 (post_7).

Dilihat dari skor pengkajian luka Bates Jensen saat pertama kali datang, semua responden berada 
pada fase luka degeneratif (skor lebih dari 13) yang artinya luka belum berada di fase remodeling (16). Lama luka responden berkaitan kemampuan tubuh responden untuk merespon infeksi yaitu dengan melakukan metabolisme untuk memproduksi materimateri melawan bakteri khususnya sel darah putih dan nutrisi untuk kelangsungan penyembuhan luka (18). Keadaan diabetes pada responden telah mempengaruhi metabolisme tubuh sehingga komponen-komponen yang seharusnya diproduksi oleh tubuh dan diangkut melalui pembuluh darah menjadi terganggu dikarenakan adanya gangguan metabolisme oleh hiperglikemia yang mempengaruhi pertumbuhan bakteri (17). Menurut sebuah penelitian adanya jaringan nekrotik, jaringan devitalisasi dan tingginya infeksi pada luka respondennya mengakibatkan peningkatan metabolisme berlebih sehingga menghasilkan hipoksia jaringan (19).

Terjadinya hipoksia jaringan mengakibatkan matriks ekstraseluler terdestruksi dan pembentukan fibroblast untuk penyembuhan luka akan terganggu yang menyebabkan lama luka responden bertambah panjang (19). Bertambah panjangnya penyembuhan luka dikarenakan sel makrofag mengidentifikasi sel hipoksia sebagai sel yang sudah tidak berfungsi lagi untuk difagositosis (13). Hal ini menyebabkan waktu yang diperlukan makrofag dalam memfagositosis bakteri atau jaringan yang tidak sehat dalam rangka autolysis debridement bertambah panjang dan untuk proses selanjutnya, sehingga fibroblast menjadi tidak berfungsi secara maksimal (13).

Hasil statistik menunjukkan bahwa rata-rata jumlah koloni bakteri pada kelompok jambu 10\% dan jambu $20 \%$ tidak terdapat perbedaan jumlah koloni bakteri dimasing-masing kelompok $(p>0,05)$. Rata-rata jumlah koloni bakteri pada setiap kelompok diatas $10^{7}$ koloni, hal ini tentu akan mempengaruhi penyembuhan luka karena luka terbuka menjadi media yang tepat sebagai perkembangbiakan bakteri. Tidak adanya perbedaan jumlah koloni bakteri kemungkinan dikarenakan faktor usia, penyakit sistemik, gangguan imun, konsumsi imunosupresan. Pada penelitian ini, rata-rata usia responden (53 tahun) menunjukkan bahwa mereka berada di fase dewasa tua dengan penyakit sistemik seperti diabetes mellitus menyebabkan terganggunya produksi ataupun fungsi dari masing-masing sel imun yang mengakibatkan luka menjadi sulit sembuh dan dapat mengarah ke luka kronik sehingga bakteri berkembangbiak diarea luka responden (20).

\section{Kelompok Jambu 10\% Sebelum dan Sesudah Pencucian Luka}

Ekstrak air daun jambu biji mengandung senyawa tannin, flavanoid dan terpenoid serta fenol (8). Secara statistik, kelompok jambu $10 \%$ terdapat pengaruh pencucian luka secara signifikan dengan nilai $p$ untuk hari pertama, hari ke- 3 , hari ke- 5 dan hari ke-7 berturut-turut adalah $p=0,008(p<0,05)$.

Mekanisme lisisnya bakteri diketahui karena tannin yang banyak terdapat di daun jambu biji dapat melisiskan protein dari membran sel bakteri. Senyawa astringen yang terdapat didalam tannin dapat menginduksi pembentukan ikatan kompleks senyawa terhadap enzim dan substrat mikroba. Awal dari kerja tannin bersama dengan fenol, flavanoid dan terpenoid diketahui mempresipitasi protein bakteri dengan menghambat sintesis protein bakteri. Dinding sel bakteri yang mengecil, lebih tipis dan abnormal ini mengakibatkan permeabilitas sel bakteri akan terganggu (21).

Penambahan logam-logam seperti $\mathrm{Mn}, \mathrm{Co}, \mathrm{Cu}$ dan Zn pada bakteri dapat meningkatkan pertumbuhan protease bakteri yang dapat dilihat dari peningkatan jumlah enzim ekstraseluler bakteri (22). Akan tetapi, ketika permeabilitas sel terganggu maka tannin bersama senyawa lain yang terkandung pada daun jambu biji dapat masuk dan berikatan dengan ion logam akan menambah daya toksisitas tannin terhadap bakteri (22). Adanya ion logam yang terkandung di dalam bakteri dan masuknya senyawa tannin terbukti membantu melisiskan bakteri dengan mekanisme inaktivasi enzim dan destruksi materi genetik (22).

Membran sel bakteri yang tersusun atas selaput sitoplasma (fosfolipid dan protein) berfungsi untuk transport aktif sel bakteri. Transport aktif dari membran sel ini sangat penting untuk kelangsungan hidup bakteri dengan mempertahankan bahan-bahan penting tetap berada di dalam sel dan dapat mengatur keluar masuknya bahan-bahan lain. Kerusakan membran sel bakteri mengakibatkan ion nukleotida, koenzim dan asam amino yang sangat dibutuhkan oleh bakteri keluar sel. Sitoplasma tidak bisa mengatur zat-zat yang dibutuhkan oleh tubuh bakteri masuk ke dalam tubuh sehingga bakteri tidak mampu tumbuh yang akan berakibat pada kegagalan organ dan kematian (23).

Waktu yang dibutuhkan untuk pencucian luka untuk setiap responden yaitu 2-3 menit. Hal ini sejatinya cukup untuk senyawa-senyawa yang ada pada ekstrak daun jambu biji merusak kandungan protein bakteri. Senyawa yang terkandung pada daun jambu biji secara 
in vivo dapat melisiskan protein bakteri hanya dalam waktu kurang dari satu menit (24).

Setiap dua hari setelah dilakukan perawatan luka, terjadi kenaikan rata-rata jumlah koloni bakteri pada responden. Hal ini dikarenakan peneliti tidak dapat mengontrol faktor-faktor yang dapat mempengaruhi jumlah koloni bakteri seperti faktor intrinsik (usia, sistem imun dan nutrisi) dan faktor ekstrinsik (teknik perawatan luka, temperatur, lingkungan) bahwa teknik perawatan luka yang tidak dapat dikontrol disebabkan karena setiap responden mendapatkan jenis dressing yang berbeda sehingga sangat memungkinkan terjadi perbedaan pertumbuhan bakteri (18).

Faktor degenerasi pada usia dewasa tua menjadi alasan peneliti sebagai faktor intrinsik yang mempengaruhi jumlah koloni bakteri. Usia dewasa tua akan mengalami penurunan fungsi dan sekresi sel-sel regenerasi. Masa pertumbuhan banyak terdapat sel mast yang membantu proses fase inflamasi dan growth factor yang banyak berperan dalam fase proliferasi sehingga membantu mempercepat terjadinya kontraksi dan epitelisasi luka (17). Usia dewasa cenderung mengalami penurunan vaskularisasi dermal, densitas kolagen, fragmentasi elastin, dan jumlah sel mast sehingga bakteri tumbuh baik ditempat dengan kriteria growth factor yang turun, respon inflamasi yang jelek dan sekresi sistem imun yang sudah menurun sehingga walaupun ada pengaruh pencucian luka, akan tetapi ketika responden datang kembali untuk merawat luka terjadi peningkatan jumlah koloni bakteri (17).

Nutrisi yang tidak dikontrol oleh peneliti menjadi penyebab peningkatan jumlah koloni bakteri selanjutnya, nutrisi responden yang berbedabeda mengakibatkan proses metabolisme tubuh yang berbeda pula. Penyakit diabetes mellitus sendiri merupakan penyakit metabolik, sehingga menyebabkan perbedaan proses penyusunan energi untuk melawan bakteri. Setiap bakteri memiliki karakteristik kondisi pertumbuhan yang berbeda-beda, pertumbuhan bakteri pada kondisi yang optimum lebih cepat jika dibandingkan dengan jamur. Hal ini disebabkan karena bakteri memiliki struktur sel yang lebih sederhana dan sebagian besar bakteri memiliki waktu generasi hanya sekitar 20 menit (23).

Beberapa faktor eksternal penyebab terjadinya peningkatan jumlah koloni bakteri disebabkan karena faktor lingkungan, pada saat dilakukan penelitian di Pontianak sedang musim hujan dan tidak sedikit responden yang datang dengan kondisi balutan yang sudah basah dan kotor. Kondisi balutan yang terkontaminasi memberikan lingkungan kondusif untuk bakteri dapat berkembang biak dalam luka ataupun balutan. Hal ini sesuai dengan hasil studi yang menyatakan bahwa berdasarkan sifat perkembangbiakan bakteri, jumlah koloni bakteri akan meningkat seiring dengan bertambahnya waktu kontaminasi luka (4).

Faktor berikutnya yaitu faktor internal dari para responden diantaranya usia, kontrol gula darah dari responden yang jelek. Rata-rata usia responden pada penelitian ini yaitu diatas 50 tahun, hal ini mengakibatkan proses degeneratif yang mempengaruhi penyembuhan luka, sehingga bakteri kembali berkembang biak di dalam luka. Hal ini sesuai dengan pendapat bahwa luka pada orang usia dewasa tua sering terjadi atropi yang mengakibatkan kontraksi luka melambat dan meningkatkan resiko terjadinya luka tidak menutup (dehiscence) sehingga bakteri dapat berkembang biak (16).

Rata-rata gula darah responden pada penelitian ini diatas $200 \mathrm{gr} / \mathrm{dl}$ tidak dapat dikontrol oleh peneliti. Hal ini mengakibatkan volume darah dipenuhi oleh gula darah daripada zat-zat darah yang seharusnya dibutuhkan untuk melawan bekteri. Didukung oleh pernyataan Bryant \& Nix, bahwa dengan meningkatnya kadar gula didalam darah otomatis menghambat pembentukan sel-sel endothelial pada fase proliferasi dan menyebabkan tidak adekuatnya mediator-mediator angiogenesis yang berakibat asupan nutrisi, oksigen, growth factor, fibroblast tidak terpenuhi sehingga tubuh tidak dapat melawan bakteri secara maksimal dan respon tubuh dalam memfagositosis bakteri menjadi menurun (13).

\section{Kelompok Jambu 20\% Sebelum dan Sesudah Pencucian Luka}

Secara statistik, kelompok jambu $20 \%$ terdapat pengaruh pencucian luka secara signifikan dengan nilai $p$ untuk hari pertama, hari ke- 3 , hari ke- 5 dan hari ke-7 berturut-turut adalah $p=0,003(p<0,05)$. Kelompok jambu $20 \%$ terbukti dapat menurunkan jumlah bakteri, walaupun dihari ke-tiga sebelum dilakukan pencucian luka terjadi kenaikan jumlah koloni bakteri yang disebabkan hampir sama dengan kelompok jambu $10 \%$ baik faktor internal maupun faktor eksternal yang terdapat pada responden. Semakin tinggi kadar flavanoid yang terkandung dalam ekstrak jambu $20 \%$, mengakibatkan proses antibakteri ataupun antioksidan menjadi semakin tinggi (8). 
Penelitian ini didukung oleh studi Chen, bahwa konsentrasi ekstrak air daun jambu biji 20\% (5g/25cc) lebih efektif membunuh bakteri dan juga membunuh sel LNCaP yang merupakan sel pencetus kanker prostat melalui proses proteolitic (25). Semakin tinggi konsentrasi ekstrak air daun jambu biji, maka efek toksisitas terhadap bakteri akan semakin tinggi yang akan menyebabkan perkembangan bakteri menjadi terhambat (21), hal ini terbukti secara statistik dari ekstrak air daun jambu biji $20 \%$ yang dapat menghilangkan banyak bakteri $(p=0,003)$ daripada ekstrak air daun jambu biji 10.

\section{Perbedaan Jumlah Koloni Bakteri Setelah Dilakukan Pencucian Luka antar Kelompok (Jambu 10\% dan Jambu 20\%)}

Berdasarkan hasil penelitian dengan uji KruskalWallis, delta selisih bakteri perawatan luka hari pertama pencucian luka dan sesudah pencucian luka pada hari ke-7 antar kelompok (kelompok Jambu 10\% dan Jambu 20\%) didapatkan nilai $p=0,368(p>0,05)$ yang artinya setelah dilakukan pencucian luka, tidak terdapat perbedaan koloni bakteri untuk kelompok Jambu $10 \%$ dan $20 \%$. Peneliti beranggapan bahwa tidak terdapatnya perbedaan selisih jumlah koloni bakteri berarti antara kelompok jambu 10\% dan 20\% diartikan sama-sama efektif dalam menghilangkan bakteri yang mencapai angka $\left(10^{7}\right)$.

Bahan-bahan yang terkandung di dalam ekstrak daun jambu biji diantaranya yaitu minyak esensial, minyak atsiri, resin dan tannin yang dapat melisiskan bakteri sehingga dapat digunakan sebagai bahan pencucian luka (8). Hal ini sesuai dengan artikel Dweck, bahwa minyak esensial mengandung eugenol, asam mallic, dan tannin yang kaya cineoland empat asam triterpenic serta tiga flavonoid, quercetin, 3-L-4-4-arabinofuranoside dan 3-L-4-pyranoside dengan aksi antibakteri yang sangat kuat (26). Pendapat tersebut juga diperkuat oleh Umeh, et al, bahwa tannin membentuk protein kaya prolin untuk menghambat sintesis protein sel bakteri (24).

Semakin tinggi konsentrasi, akan semakin tinggi pula daya antibakteri bahan-bahan yang terkandung dalam ekstrak air daun jambu biji (8). Hal ini sesuai dengan hasil statistik bahwa jambu $20 \%$ dikatakan lebih efektif dengan $p=0,003(p<0,05)$ bila dibandingkan dengan jambu $10 \%$ dengan $p=0,008(p<0,05)$. Pendapat tersebut diperkuat oleh hasil penelitian Bagchi, yang menyatakan bahwa flavonoid yang tekandung dalam ekstrak air daun jambu biji memiliki aktivitas penghambatan terhadap organsime yang merugikan karena kemampuan antioksidan yang lebih kuat dibandingkan dengan vitamin $\mathrm{C}$ dan $\mathrm{E}$ tergantung konsentrasi uji (27). Semakin tinggi konsentrasi ekstrak air daun jambu biji, maka flavonoid akan semakin tinggi kemampuan antioksidan terhadap koloni bakteri yang terdapat pada luka (27). Oleh sebab itu, peneliti menarik kesimpulan bahwa jambu $20 \%$ lebih efektif dalam menurunkan jumlah koloni bakteri karena kandungan yang dapat melisiskan dinding sel bakteri serta konsentrasi yang lebih tinggi dari dari pada jambu $10 \%$ sebagai antioksidan.

\section{SIMPULAN DAN SARAN}

Berdasarkan hasil dan bahasan ekstrak air daun jambu biji $20 \%$ lebih efektif dalam mengilangkan koloni bakteri daripada ekstrak air daun jambu biji $10 \%$. Praktisi luka, khususnya perawat disarankan mengaplikasikan metode pencucian luka (cleansing) dengan menggunakan ekstrak air daun jambu biji $20 \%$.

\section{RUJUKAN}

1. Kruse I. Evaluation and Treatment of Diabetic Foot Ulcers. Clin Diabetes [Internet]. 2006 Apr 1;24(2):91-3. Available from: http:// clinical.diabetesjournals.org/cgi/doi/10.2337/ diaclin.24.2.91

2. World Health Organization. WHO, 10 Facts about Diabetes [Internet]. 2013. Available from: http:// www.who.int/features/factfiles/diabetes/facts/en/ index7.html

3. Baranoski, Ayello. Wound Care Essensials Practice Principles. Philadelphia: Lippincott Williams \& Wilkins; 2012.

4. Sumarno, REK, Rahmania NL. Perbedaan Jumlah Bakteri antara Pencucian Luka Terkontaminasi Menggunakan Normal Salin 0,9\% dengan Metode Irigasi Tekanan Plabottle (0,1-0,3 psi) Dibandingkan dengan Tekanan Selang Infus (1,41,7 psi) pada Tikus Putih Rattus Norvegicus Strain Wistar [Internet]. 2007. Available from: https://www. scribd.com/doc/91807092/Perbedaan-jumlahbakteri-antara-pencucian-luka-terkontaminasimenggunakan-normal-salin-0-9-dengan-metodeirigasi-tekanan-PLABOTTLE-0-1-0-3-PSI-dib

5. Gitarja WS. Seri Perawatan Luka Terpadu: Perawatan Luka Diabetes. Bogor: Wocare Publishing; 2008. 
6. Anas K, Jayasree PR, Vijayakumar T, Manish Kumar PR. In Vitro Antibacterial Activity of Psidium Guajava Linn. Leaf Extract on Clinical Isolates of Multidrug Resistant Staphylococcus Aureus. Indian J Exp Biol [Internet]. 2008 Jan;46(1):41-6. Available from: http://www.ncbi.nlm.nih.gov/pubmed/18697570

7. Roy CK, Das AK. Comparative Evaluation of Different Extracts of Leaves of Psidium Guajava Linn. For Hepatoprotective Activity. Pak J Pharm Sci [Internet]. 2010 Jan;23(1):15-20. Available from: http://www.ncbi.nlm.nih.gov/pubmed/20067861

8. Muhammad Abubakar E-M. The use of Psidium guajava Linn. in treating wound, skin and soft tissue infections. Sci Res Essay [Internet]. 2009 [cited 2017 Sep 15];4(6):605-11. Available from: http://www. academicjournals.org/SRE

9. Nursalam. Konsep Dan Penerapan Metodologi Penelitian IImu Keperawatan Pedoman Skripsi, Tesis, dan Istrumen Penelitian Keperawatan. 2nd ed. Jakarta: Salemba Medika; 2008.

10. Badan Pengawas Obat dan Makanan Republik Indonesia. Acuan Sediaan Herbal. 1st ed. Vol. 5. Jakarta: Direktorat OAI, Deputi II, Badan POM RI; 2010.

11. Sastroasmoro S. Dasar-dasar Metodologi Penelitian Klinis. 4th ed. Jakarta: CV Sagung Seto; 2011.

12. Siddiqui, Bernstein. Chronic Wound Infection: Facts and Controversies. Clinics in Dermatology. Elsevier, Inc; 2010.

13. Bryant, Nix. Acute \& Chronic Wounds: Current Management Concepts. 3rd ed. USA: Elsevier inc; 2007.

14. American Diabetes Association. Are You at Risk? Lower Your Risk, Age, Race, Gender \& Family History [Internet]. 2014. Available from: http:// www.diabetes.org/are-you-at-risk/lower-your-risk/ nonmodifiables.html

15. Barnabas O, Wang H, Gao X-M. Role of Estrogen in Angiogenesis in Cardiovascular Diseases. J Geriatr Cardiol [Internet]. 2013 Dec;10(4):377-82. Available from: http://www.ncbi.nlm.nih.gov/ pubmed/24454332

16. Sussman C, Jensen, Barbara B. Wound care A Collaborative Practice Manual for Health Professionals. 4th ed. Philadelphia: Lippincott Williams \& Wilkins; 2012.

17. Suriadi. Manajemen Luka. Pontianak: STIKEP Muhammadiyah; 2007.
18. Perdanakusuma. Luka. Surabaya: Departemen Bedah Plastik Rekonstruksi dan Estetik; 2012.

19. Gethin G. The significance of surface $\mathrm{pH}$ in chronic wounds. Wound UK [Internet]. 2007 [cited 2017 Sep 15];3(3):52-6. Available from: https:// pdfs.semanticscholar.org/0667/28b9c9271885a 0cbc8faf3932b42c6ec48c8.pdf

20. Davis PJ. The Immunology of Wound Healing: The Body as Battlefield. Wound Heal Sci. 2008;4(4).

21. Ajizah A. Sensitivitas salmonella typhimurium terhadap ekstrak daun Psidium guajava. BIOSCIENTIAE [Internet]. 2004 [cited 2017 Sep 15];1(1):31-8. Available from: http://bioscientiae. tripod.com/v1n1/v1_n1_ajizah.PDF

22. Susanto JP. Pengaruh Logam dan Konsentrasi Substrat terhadap Pertumbuhan dan Aktivitas Bakteri Proteolitik pada Proses Deproteinasi Cangkang Rajungan. J Teknol Lingkung [Internet]. 2011 Sep 15 [cited 2017 Sep 15];4(1). Available from: http://ejurnal.bppt.go.id/index.php/JTL/ article/view/271

23. Volk W, Wheeler M. MikrobiologiDasar. 1st ed. Jakarta: Erlangga; 1993.

24. Umeh E, Oluma H, Igoli J. Antibacterial Screening of Local Plants Using Indicator-based Microdilution Techniques. African J Tradit Complement Altern Med AJTCAM [Internet]. 2005 [cited 2017 Sep 15];2(3). Available from: http://journals. sfu.ca/africanem/index.php/ajtcam/article/ viewArticle/27

25. Chen K-C, Peng C-C, Chiu W-T, Cheng Y-T, Huang G-T, Hsieh C-L, et al. Action Mechanism and Signal Pathways of Psidium guajava $L$. aqueous extract in killing prostate cancer $\mathrm{LNCaP}$ cells. Nutr Cancer [Internet]. 2010;62(2):260-70. Available from: http://www.ncbi.nlm.nih.gov/ pubmed/20099201

26. Dweck AC. A review of Guava (Psidium guajava). [cited 2017 Sep 15]; Available from: http://www. dweckdata.com/Published_papers/Psidium_ guajava.pdf

27. Bagchi M, Milnes M, Williams C, Balmoori J, Ye X, Stohs S, et al. Acute and Chronic StressInduced Oxidative Gastrointestinal Injury in Rats, and The Protective Ability of a Novel Grape Seed proanthocyanidin Extract. Nutr Res [Internet]. 1999 Aug;19(8):1189-99. Available from: http://linkinghub.elsevier.com/retrieve/pii/ S0271531799000809 